\title{
İșletme Stratejileri Perspektifinden Stratejik Yönetim Okulları
}

\section{Dr. Murat Yolsal ${ }^{1 *}$}

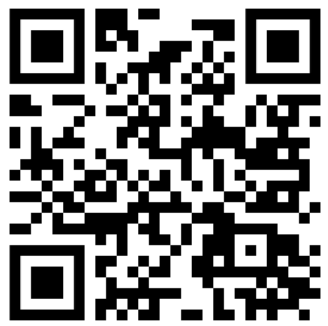

Geliș tarihi: 28.09.2020

Kabul tarihi: 11.11.2020

\section{Atıf bilgisi:}

IBAD Sosyal Bilimler Dergisi

Sayı: Özel Sayı Sayfa: 317-334

Yıl: 2020

This article was checked by Turnitin. Similarity Index 07\%

1 İstanbul Ticaret Üniversitesi, Türkiye, muratyolsal@gmail.com.

ORCID ID 0000-0001-5446-7683

* Sorumlu yazar
ÖZ

Bu çalışmada Henry Mintzberg'in on stratejik yönetim okulu, birbirinin zıddı olan iki temel işletme stratejisi açısından ele alınmıştır. Çalışmanın kapsamı üç yönden sınırlandırılmıştır. Bunlardan ilki stratejik yönetim okullarının ele alınmas konusudur. Stratejik yönetim yaklaşımları konusunda, farklı araştırmacılar farklı taksonomiler geliştirmişlerdir. Fakat bu taksonomileri derinlik arz eden bir bütünlüğe kavuşturanın Henry Mintzberg olduğu, akademik çevrelerce geniş bir kabul görmektedir. Bu sebepten ötürü çalıșma Mintzberg'in yönetim okullarıyla sınırlandırılmıştır. İkincisi işletme stratejileri konusundadır. Bu noktada çalışma, günümüzün temel iki yaklaşımı olan pazar yaklaşımı ile kaynak tabanlı görüşü karşı karşıya getirmeyi amaçlamış ve yönetim okulları, yöntemsel olarak önceden gerçekleştirilmiş vaka analizleri bağlamında değerlendirmiştir. İlerleyen sayfalarda okuyucu, bazı yönetim okullarının pazar yaklaşımına, bazılarının kaynak tabanlı yaklaşıma yakın olduğuna, bazı okulların ise her iki yaklaşımı bütünleştirdiğine şahit olacaktır. Üçüncüsü kısıt ise çalışmanın stratejik yönetim düşüncesi tarihine yön veren makro düzeydeki olay ve olguları çalışmanın kapsamı dışında bırakmasıdır. Bu bağlamda, ilgi duyan okurlar, mikro düzeyde beliren yönetim okullarının makro düzeydeki arka planını anlatan çeşitli kitaplardan faydalanabilirler.

Anahtar Kelimeler: İşletme Stratejileri, Stratejik Yönetim Okulları, Pazar Yaklaşımı, Kaynak Tabanlı Görüş. 


\section{Strategic Management Schools from the Perspective of Business Strategies}

\section{Dr. Murat Yolsal ${ }^{{ }^{*}}$}

First received: 28.09 .2020

Accepted: 11.11 .2020

\section{Citation:}

IBAD Journal of Social Sciences

Issue: Special Issue Pages: 317-334

Year: 2020

This article was checked by Turnitin. Similarity Index 07\%

1 İstanbul Ticaret University, Turkey, muratyolsal@gmail.com,

ORCID ID 0000-0001-5446-7683

Keywords: Business Strategies, Strategic Management Schools, Market Approach, Resource Based View.

In this study, Henry Mintzberg's ten strategic management schools are dealt with in terms of two opposite business strategies. The scope of the study is limited in three ways. The first is the issue of addressing strategic management schools. As regards strategic management approaches, different researchers have developed different taxonomies. However, it is widely accepted by academic circles that Henry Mintzberg brought these taxonomies to a deeper integrity. For this reason, the study is limited to the management schools of Mintzberg. The second concerns business strategies. At this point, the study aimed to confront the two main approaches, the market approach, and the source-based view, and evaluated the management schools in this context. In the following pages, the reader will witness that some management schools are close to the market approach, some are close to the resource-based approach, and some schools integrate both approaches. Third limitation is that the study excludes macro-level events and facts that shape the history of strategic management thought. In this context, interested readers can benefit from various books describing the macro level background of the management schools that occur at the micro level.

* Corresponding Author 


\section{GİRIŞ}

Bu çalışmada, birbirinin zıddı olan iki temel işletme stratejisi ele alınacaktır. Yurt dışı yazında ilgili stratejiler, market approach (pazar yaklaşımı) ve resource - based view (kaynak tabanlı görüş) olarak isimlendirilmiștir. Bu stratejilerin açıklanması konusunda yabancı yazın yurt içi yazından çok daha kapsamlı ve tatmin edici olduğundan, bu çalışmada ilgili stratejiler, pazar yaklaşımı ve kaynak tabanlı görüş olarak adlandırılacaklardır. Pazar yaklaşımı ile kaynak tabanlı görüş arasındaki temel fark, işletme yönetim stratejisini belirlerken görünürlük kazanmaktadır. Bu doğrultuda, işletme strateji geliştirirken dış çevreye (pazar yaklaşımı) ya da kendi güçlü yönlerine (kaynak tabanlı görüş) odaklanabilir. Günümüz pandemi koşullarında, her bir yönetim okulu için ayrı ayrı kapsamlı vaka analizleri gerçekleştirmek çok zor olacağı için, araştırmanın yöntemi, her bir stratejik yönetim okulu için geçmişte yapılmış başaralı vaka analizlerinin değerlendirilmesine dayanmaktadır.

\section{PAZAR YAKLAŞIMI}

Pazar yaklaşımının akademik çevrelerde dile getirilmesi 1970'li yıllara uzanmasına rağmen, bu görüşün temel bir işletme stratejisi olarak benimsenmesi Michael Porter sayesinde gerçekleşmiştir. Porter'ın pazar yaklaşımına en büyük katkısı dış çevreyi daraltarak, işletmenin faaliyet gösterdiği sektör ile sınırlandırması olmuştur. Bu bağlamda, öncülleri tarafından dış çevreye dâhil edilen sektör dışı ikincil unsurlar, Porter tarafından devre dışı bırakılmışlardır (Barca, 2009, s. 42). Dış çevreyi, "sektörel çevre" ile sinırlandıran Porter, bu çevrenin beş temel aktörden meydana geldiğini savunmuştur: Müssteriler, mevcut rakipler, yeni yatırımcılar, ikame mal üreticileri ve tedarikçiler. $\mathrm{Bu}$ beş faktörün yarattığı etkinin toplamı ile ilgili sektördeki rekabet yoğunluğu bulunur. Bu yoğunluk sektörden sektöre değişkenlikler arz eder ki, bu durum da her sektörde farklı rekabet oyunlarına ve getiri potansiyellerine yol açar (Barca, 2009, s. 42 - 43).

Henry'e (2008, s. 69) göre, Porter'ın yukarıda değinilen beş faktörlü yaklaşımı, yönetim okullarına nüfuz etmiş ve günümüzde de halen kabul gören en önemli yönetim stratejisidir. Yazar, beş faktörlü yaklaşımın, bir işletmenin ilgi gösterdiği sektörde piyasaya girip, piyasadaki diğer oyuncularla rekabet etmesi konusunda kusursuz bir sistematik çerçeve sunduğunu belirtmektedir. Porter'ın rekabet yoğunluğu kavramını irdeleyen Bea-Haas (2005, s. 27) ise faktörlerin etkilerinin toplamı ne kadar yüksekse rekabetin o kadar çetin, buna karşıllk sektörün cazibesinin de o derece düşük olduğunu dile getirmişlerdir. Diğer yandan, ilgili sektördeki tüm kaynakları homojen kabul edip, kaynakların sınırsız hareket ettiğini varsayması, yaklaşıma getirilen en temel eleştiridir. Bu ön kabule göre tüm firmalar hemen hemen aynı kaynaklara sahiptir ve bazı firmaların rakiplerinde olmayan kaynaklara sahip olma girişimleri, pazar mekanizması tarafından hemen engellenmektedir. Kısacası, pazar yaklaşımı, sahip olunan kaynakların, işletmeye rekabet avantaj1 getirmeyeceğini savunmaktadır (Rumelt, 1991 s. 66; Wolf, 2005, s. 415 - 416). Piyasada yapılan ayrıntılı sektör tabanlı çözümlemeler ise, firmalar arasındaki performans farklarının, sektörel çevrede ziyade işletmenin yetkinlik ve kabiliyetlerinden kaynaklandığını ortaya koymaktadır. $\mathrm{Bu}$ doğrultuda, sadece dış çevreye odaklanmış pazar yaklaşımının, firmaların performans farklarını ölçmede tek ölçüt olarak kullanılamayacağı söylenebilir (Rumelt, 1991, s. 179; Knecht, 2014, s. 19).

\section{KAYNAK TABANLI GÖRÜŞ}

Kaynak tabanlı görüşün öncüsü Birger Wernerfelt'tir. Wernerfelt'in 1984 tarihli Kaynak Tabanlı Görüş adını taşıyan yüksek lisans tezi, daha sonra Strategic Management Journal tarafından yayımlanmıştır. Lakin yaklaşım temel bir işletme stratejisine dönüşmesini, Jay Barney tarafından kaleme alınıp, Journal of Management Dergisi'nde yayımlanan ünlü "Firma Kaynaklart ve Sürdürülebilir Rekabet Avantajı" adlı makaleye borçludur. Bu makalesinde Barney, işletme kaynaklarını üç temel kategoride sınıflandırmıştır (Pearce-Robinson, 2015, s. 154):

Maddi Varlıklar: İşletme bilançosundan kolaylıkla tanımlanabilen hammadde, finansal kaynaklar, makine - donanım gibi, işletme girdilerinin çıktılara dönüştürülme sürecinde kullanılan fiziki ve finansal kaynaklardır.

Maddi Olmayan Varlıklar: Alametifarikalar, lisanslar (izin), ruhsatlar (özel izin) patentler (icat), firma itibarı, bir şeyi yapabilme bilgisi (know-how) vb. somut nitelik taşımayan rekabet avantajı yaratma 
potansiyeline sahip kaynaklardır.

Örgütsel Kabiliyetler: İşletmenin, müşterilerine katma değer yaratmak adına, maddi ve maddi olmayan varlıklarını, iş süreçlerini ve insan kaynaklarını bir araya getirebilme becerisidir.

$\mathrm{Bu}$ bağlamda işletmenin kaynaklarının bazıları rekabet avantajı sağlamaya uygunken, bazılarının yapısı da buna elverişli değildir. İşletme kaynağının rekabet avantajı sağlama potansiyeline sahip olabilmesi için dört temel özelliğe sahip olması gerekmektedir (Barney, 1991, s. 106):

Değerlilik: İşletmeye ait bir kaynak veya kabiliyet aşağıdaki özelliklerde birkaçını ya da hepsini taşıyorsa "değerli" olarak tanımlanabilir (Pearce ve Robinson, 2015, s. 156). İșletmeye ait bir kaynak, işletmenin kontrolü altındaysa ve işletmenin karlılığında önemli bir yer tutuyorsa, işletmeye katma değer sağlıyorsa, uzun süre faydalanılabilir nitelikte ise ve müşteri istek ve ihtiyaçlarının karşılanmasında kritik nitelikte ise, değerlidir.

Nadirlik: Değerli bir kaynağın rekabet avantajı kazandırabilmesi için, ilgili kaynağın işletmenin güncel ve potansiyel rakipleri arasında nadir bulunabilir olması gerekmektedir (Barney, 1991, s. 106). Şayet, ilgili kaynağı ya da yetkinliği rakipler de kolayca elde edebiliyorlarsa, bu durumda kaynak, ilgili işletmeye, rakipler kendisine erişene kadar geçici bir rekabet avantaj1 sağlar (Bal, 2010, s. 271; Knecht, 2014, s. 22). Çok kısıtlı miktarlarda bulunan tabii kaynaklar, avantajlı bir fabrika güzergâhı, kaynağın nadirliğine örnek olarak verilebilirler (Pearce ve Robinson, 2015, s. 156). Dikkat edilmesi gereken bir diğer konu ise, bir kaynağın rekabet avantajına sahip olamamasının onu değersiz kılmayacă̆ıdır. Aksine değerli ama rekabet avantajına sahip olmayan kaynaklar genelde, asli kanyaklardır (Bal, 2010, s. 271). (Örneğin, hammadde, demirbaşlar vb.) ve bu tarz kaynaklar genelde firma faaliyet gösterdiği sürece işletme bünyesinde bulunurlar.

Taklit Edilemezlik: Değerli ve nadir kaynaklar, ancak bu kaynaklara sahip olmayan işletmeler tarafından taklit edilemediklerinde sürdürülebilir rekabet avantajı sağlarlar. Aksi takdirde, geçici rekabet avantaj1, rakipler kaynağı taklit edince sona erer (Barney, 1991, s. 107). Örneğin, Wendy's fast food sektörüne ilk girdiğinde, arabalara hamburger servisi yapan tek hamburger zinciri idi. Lakin firmanın bu örgütsel kabiliyeti kısa sürede tüm fast food zincirleri tarafından taklit edilmeye başlandığı için bu örgütsel kabiliyet kısa sürede nadirliğini ve değerini de yitirdi (Pearce ve Robinson, 2015, s. 157). Bal'a (2010, s. 272) göre, rekabet halinde olan firmalar bazı özel koşullarda, işletmenin kaynağını taklit etmede başarılı olamazlar. Bu durumda ilgili işletmenin rekabet avantajı sürekli bir hal alır. Bu özel koşullar bazen zamanla ilişkili olup (örneğin, taklidin çok uzun zaman alması) bazen de maliyetle ilgilidir (örneğin taklidin ilave bir yatırımı gerektirmesi).

Bu bağlamda, Barney ve diğerleri. (2001, s. 636) örgütlerin iş etiği ile ilgili olarak geliştirdikleri çeşitli normları taklit edilemez olduğunu ileri sürmüşlerdir.

İkame Edilmezlik: Morgan ve Hunt'a (1999, s. 282) göre, örgütler rakiplerine karş1 sürdürülebilir rekabet avantajı sağlamak adına, kaynaklarının kolayca ikame edilmesini arzu etmezler. Kaynak ikamesi iki şekildedir (Barney, 1991, s. 111 - 112):

Bunlardan ilki, A işletmesinin ihtiyaç duyduğu ve temin edemediği B işletmesinin ürettiği kaynağın (örneğin yarı mamulün) benzerini $\mathrm{C}$ işletmesinden ikame etmesidir. İkinci durum ise, birbirinden çok farklı kaynakların ikame unsuru olarak kullanabilmesidir. Örneğin, A firmasının ürettiği bir ürün, tamamen farklı bir sektörde faaliyet gösteren ve farklı bir ticari faaliyetle iştigal eden B firması için ikame edilebilir kaynak durumunda olabilir. 
Şekil 1. Sürdürülebilir Rekabet Avantajına Sahip Kaynak (Rothaermel, 2013, s. 91).

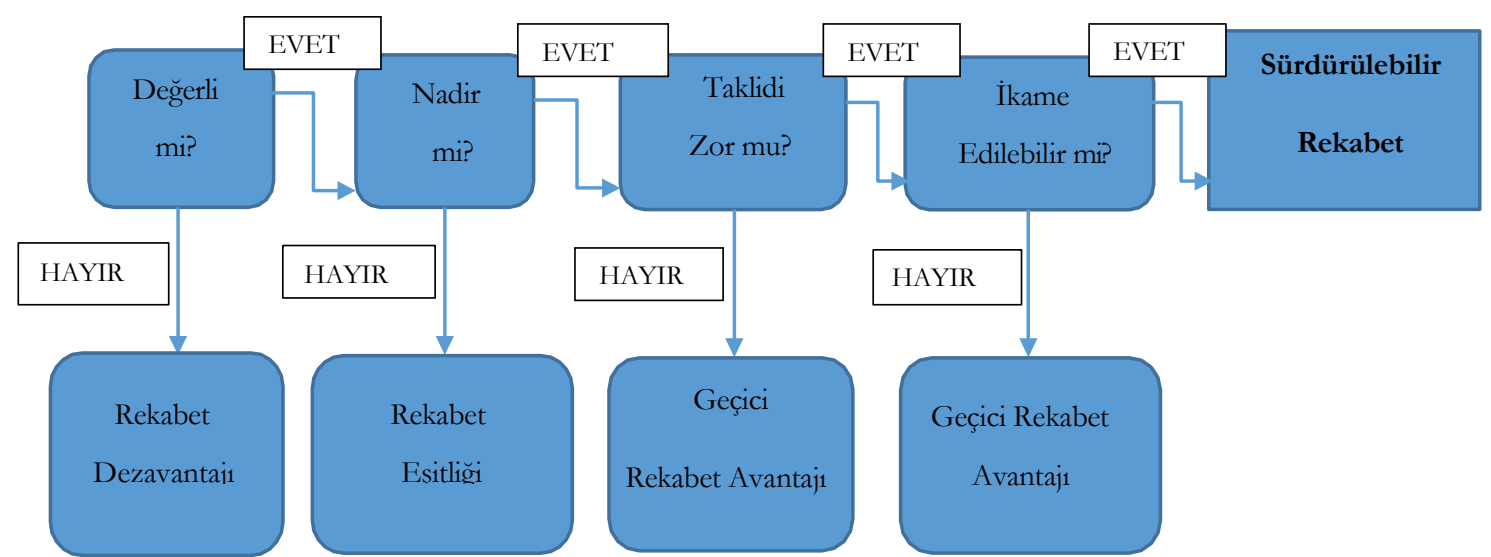

Kaynak tabanlı yaklaşım, pazar yaklaşımının, sektöre bağlı çevresel faktörlere odaklanan stratejisine gösterilmiş bir tepki olarak da kabul edilebilir. Bu görüş, muğlak ve değişken bir pazara yoğunlaşmaktansa, firmaya kendi kaynak ve kabiliyetlerini temel alarak strateji geliştirmesini salık vererek, ona hareket serbestisi kazandırarak manevra alanını genişletmektedir (Barca, 2009, s. 50). Kaynak tabanlı yaklaşımın en önemli eksiği ise yaklaşımın en başta sorması gereken soruyu ihmal etmesinden kaynaklanmaktadır: İşletmeler yığınla kaynak arasından, bazılarının kendilerine uzun vadede rekabet avantajı sağlayacağını nasıl tahmin edeceklerdir?

$\mathrm{Bu}$ tahmini hangi varsayımlara dayandıracaklardır? Bugün stratejik rekabet avantajı sağlamayan bir kaynak, yarın piyasa koşulları değiştiği için rekabet avantajı sağlayabilir mi? Ayrıca pek çok akademisyen ve örgüt kuramcısı da, Barney tarafindan öne sürülen rekabet avantajı yaratma şartlarını oldukça muğlak ve belirsiz bulmaktadır (Knecht, 2014, s. 24).

Her ne kadar ilk bakışta, iki temel işletme stratejisi birbirlerinin zıddı perspektifler sunsalar da aslında aralarında oldukça yakın bir ilişkinin varlığından söz etmek mümkündür. Kaynak tabanlı görüşün kuramcısı Wernerfelt (1984, s. 171) bu doğrultuda, iki yaklaşımı "demir paranın iki yüzü" olarak nitelendirmiş, biri olmadan diğerinin de var olamayacağını eklemeyi de ihmal etmemiştir. Benzer şekilde, Bamberger-Wrona (1996, s. 147) da iki yaklaşımın birbirlerini bütünlediğini dile getirmişlerdir. Sonuç olarak, işletmelerin, faaliyet gösterdikleri sektörün yapısı ile kendi kaynak ve kabiliyetlerinin durumu hangi temel yönetim okulu stratejisine ya da stratejilerine uygun ise o doğrultuda hareket etmeleri kendileri için daha anlamlı olabilmektedir.

\section{ON STRATEJIKK YÖNETIM OKULU}

$\mathrm{Bu}$ bölümde Henry Mintzberg tarafından geliştirilen on stratejik yönetim okulu incelenecektir. Öncelikle her bir okul hakkında kısaca bilgi verilerek, ilgili okulun temel varsayımlarının hangi işletme stratejisine daha yakın olduğuna değinilecek, sonrasında ise geçmişte yapılmış vaka analizleri aracılığıla teorik bilginin pratikteki yansıması okurla paylaşılacaktır.

\subsection{Tasarım Okulu}

Tasarım okulu stratejik yönetim okullarının en eskisidir. Bu okulun temel kavramları Harvard Yönetim Okulu'ndan Kenneth Andrews, Berkeley Üniversitesi’nden Philip Selznick ve MIT profesörü Alfred Chandler tarafindan geliştirilmiştir (Sarvan ve diğerleri, 2003, s. 75).

Tasarım okulu, stratejinin ne olduğu ve ne yaptı̆̆ ile ilgilenmek yerine, nasıl olması gerektiğini açıklayarak kural koyucu bir yaklaşımı benimser (Bakoğlu-Dinç Özcan, 2010, s. 60). Strateji geliştirme sürecini kontrollü ve bilinçli bir zihni çabaya dayandırılırken, diğer yandan sürecin basit ve gayri resmi olması gerektiğinin de altı çizilmektedir (Sarvan ve diğerleri, 2003, s. 75). Tasarım Okulu'nun önemle vurguladığı temel kavram dengedir. Strateji oluşturma süreci, işletmenin dâhili kaynaklarının güç ve zaaflarıyla, harici çevrenin tehdit ve firsatları arasındaki dengenin kurulmasıyla ortaya çıkar. (Dinçer, 2013, s. 148; Sarbah-Otu-Nyarko, 2014, s. 231). Bu bağlamda okulun fikir 
babalarından Andrews'in geliştirdiği SWOT analizi, işletmenin güçlü ve zayıf yönleri ile pazarın firsat ve tehditlerini birlikte değerlendirmektedir (Barca, 2009, s. 37). Okul, strateji geliştirme sorumluluğunu işletmenin tepe yöneticilerine vererek, stratejiyi ilk kez bilinçli bir süreç olarak ele almasına rağmen, strateji geliştirmeyi statik bir şekilde aşırı basitleştirdiği için eleştirilmektedir (Sarvan ve diğerleri, 2003, s. 75). Diğer yandan işletme örgütsel düzeydeki stratejisini belirlerken, firmanın dış çevresini dikkate alması gerektiğine vurgu yapan pazar yaklaşımı ile iç unsurlarını göz önünde bulundurmasını salık veren kaynak tabanlı görüşü bütünleştirir (Bakoğlu-Dinç Özcan, 2010, s. 61).

\section{Vaka Analizi: Amazon.com}

1994 yılında kurulan Amazon.com, işe önce kitap satarak başlayan bir e-ticaret öncüsüdür. Bugün Amazon'da kitap haricinde, DVD, CD, bilgisayar yazılımı, elektronik eşya, mobilya, aksesuar vb. farkı türden ürünler satılmaktadır. İşletmenin temel stratejisi hem kurucusu hem de tepe yöneticisi olan Jeff Bezos tarafından geliştirilmiştir. Bu doğrultuda Bezos'un bilinçli zihinsel çabası sayesinde (Sarbah-Otu-Nyarko, 2014, s. 239): Şirket adının, sanal alışverişte önde çıkması için «A» harfi ile başlaması tercih edildi. Sitede A'dan Z'ye her şeyi bu sitede bulabileceğimiz algısını yaratmak için özel bir logo geliştirildi. Ayrıca, Amazon.com faaliyet gösterdiği temel sektörlerde, kendi kaynak ve yetkinliklerinden azami fayda sağlamaktadır (Kaynak tabanlı görüş). Bu kabiliyetlerin bazıları da (Sarbah-Otu-Nyarko, 2014, s. 239): Sofistike çevrimiçi satış teknolojileri ve güvenilir IT sistemleri, Özel müşteriler için farklı teslimat seçenekleri (Örnek: Drone ile adrese teslimat seçeneği). Amazon.com, strateji geliştirirken, kendi kaynak ve yetkinliklerinin haricinde, rakiplerinin faaliyet gösterdiği pazarları da dikkate almaktadır. $\mathrm{Bu}$ bağlamda, işletmenin pazar yaklaşımının temel varsayımlarına da yakın durduğunu söylemek yanlış olmayacaktır (Sarbah-Otu-Nyarko, 2014, s. 244).

Şirketin periyodik olarak gerçekleştirdiği rekabet analizi, Amazon.com'un en önemli rakiplerinin Barnes and Nobles.com, Ebay.com ve Walmart.com olduğunu ortaya koymaktadır. Barnes and Nobles.com, kitap ve yaşam stili ile ilgili ürünlerde, işletmenin doğrudan rakibidir. Amazon.com, Barnes and Nobles'ten daha geniş bir ürün portföyüne sahiptir. Walmart.com ise fotoğraf, lens ve ilaç sanayi ile ilgili ürünlerde Amazon.com'un direkt rakibi olup, müşterilerine daha geniş bir ürün yelpazesini benzer fiyatlardan sunmaktadır. Diğer bir rakip Ebay.com, daha geniş bir coğrafi alanda daha çok ürünü nispeten daha yüksek fiyatlardan müşterilerine sunmaktadır.

\subsection{Planlama Okulu}

Planlama okulu da öncülü Tasarım Okulu gibi kural koyucu bir yaklaşımı benimsemektedir. Tasarım okulundan farklı olarak, strateji oluşturma sürecini bilinçli bir zihinsel çaba ile sinırlandırmamakta, bu süreci yazılı olarak da resmileştirmektedir. Bu doğrultuda strateji, en ince ayrıntısına kadar alt kategorilere ayrılmış bir plandır (Bakoğlu-Dinç Özcan, 2010, s. 61). Diğer yandan, stratejileri belirleme ve uygulama sorumluluğu genellikle dışarıdan atanan planlamacılara bırakılmıştır. Okul, bir danışmanın, değişim ajanının ya da bu şahıslardan oluşan bir takımın, planlamacı olarak vazifesini ifa edebileceğini belirtmektedir (Sarvan ve diğerleri, 2003, s. 78).

Planlama okulunun stratejisi, ilgili işletme ile dış çevresi arasındaki ilişkiye dayanmaktadır. $\mathrm{Bu}$ bağlamda, firma harici rekabet durumunu tarafsız bir gözle idrak etmek ve kendisine en yüksek rekabet avantajını sağlayacak faaliyet sahasını seçmekle mükelleftir. Dikkatini dış pazara yoğunlaştıran işletme, faaliyet gösterdiği sektörü çözümlemeli, risk raporları ve ayrıntılı bütçe oluşturmalıdır (Mintzberg, 1994, s. 112). Ansoff tarafından önerilen boşluk analizi de; yukarıda açıklanan yaklaşım doğrultusunda; işletmenin faaliyet gösterdiği pazardaki mevcut konumu ile arzuladığı konum arasındaki farkın tanımlanmasını sağlar ve bu farkın nasıl kapatılacağına ilişkin tavsiyelerde bulunur (Barca, 2009, s. 38). Yukarıdaki açıklamalardan da anlaşılabileceği gibi planlama okulu stratejisini faaliyet gösterdiği sektöre ve rakiplerine göre oluşturduğu için, bu okulun temel çıkarımlarının pazar yaklaşımı ile örtüştüğünü söyleyebiliriz (Bakoğlu-Dinç Özcan, 2010, s. 62).

\section{Vaka Analizi: Coca - Cola}

Coca - Cola, 200’ün üzerinde ülkede faaliyet gösteren, dünyanın en önemli alkolsüz gazlı içecek 
firmalarından birisidir. Coca - Cola markası (iç kaynak), dünyanın en değerli alameti - farikalarından biri olmasına karşın, firmanın temel stratejisi pazar ve ürün odaklı ayrıntılı iş geliştirme planlarına dayanmaktadır. Coca -Cola'nı iş geliştirme stratejisinin dört temel sacayağı bulunmaktadır: (27 Mayıs 2020 tarihinde https://themarketingagenda.com/2015/03/28/COCA-COLA-ANSOFFMATRIX/adresinden erişildi). Pazara nüfuz etme, Mevcut ürünle, mevcut pazarda yeni müşteriler bulma. Noel süresince gerçekleştirilen yoğun reklam kampanyası aracılığıyla hedef tüketici kitlede, içecek ile Noel arasında ilişki olduğuna dair bir alg1 yaratmayı amaçlar. Pazar geliştirme: Mevcut ürünü yeni bir pazara uyarlayarak yeni müşteri deneyimi yaratmak. Hedef kitlesi zayıflamak isteyen kadınlar olan Light Cola yerine birebir aynı özelliklere sahip Coca Cola Zero ürünüyle, erkek müşterileri de müşteri portföyüne dâhil etmeyi hedefler. Ürün geliştirme: Mevcut pazara yeni bir ürün sunarak, pazar payını arttırma. Klasik Coca Cola tadının yanında vanilyalı ve kirazlı seçenekleri de hedef kitlesine sunar. Çeşitlendirme ise yeni pazarlara yeni ürünleri iki şekilde sunabilir. Bunlardan ilki ilişkili ürün sunmadır (Örnek: Glaceau Enerji İçeceği). Diğer yandan, firma, kendi temel faaliyet alanının (alkolsüz içecekler) dışına çıkarak, farklı ürünleri de (tekstil ürünleri) piyasaya sürebilir.

\subsection{Pozisyon Okulu}

$\mathrm{Bu}$ okulun asıl gelişimi ve stratejik yönetim akademik camiasında düşünce okulu olarak kabul edilmesi, Harvard Üniversitesi İşletme profesörü Michael Porter tarafından 1980 yılında kaleme alınan Rekabet Stratejileri adlı kitaba dayanmaktadır.

Konumlandırma okulu olarak da adlandırılan bu yaklaşım kendisinden önceki iki okul gibi kural koyucudur. Lakin öncülü olan okulların temel çıkarımlarına uymakla birlikte, onlardan farklı olarak, bir endüstride hangi stratejinin benimseneceğine dair önerilerde bulunmaktadır (Sarvan ve diğerleri, 2003, s. 80). Bu okula göre, başarılı olmak için işletme faaliyet gösterdiği sektördeki rakiplerine karş1 aşağıda kısaca açıklanan üç temel stratejiden birini seçerek bir pozisyon alır. Farklılaşmada, rakip ürünlerden farklı özellik ve fonksiyonlara sahip ürünler üretilir; maliyet liderliğinde, standart ürünler rakiplerden daha düşük maliyetle üretilir; odaklanmada ise, geniş bir pazara hitap etmek yerine, dar ve niş bir pazara yoğunlaşı1ır (Porter, 1980, s. 35).

Teece'e göre (1984, s. 94), bu stratejilerden herhangi biri sayesinde ilgili işletme, rakiplerinin belirlediği fiyatlara göre pozisyon alan edilgen bir konumdan, piyasa şartlarını ve fiyatları belirleyen etken bir konuma geçmekte ve piyasaya hâkim bir aktör olma şansını yakalamaktadır. Porter (1985 s. 17), bu üç stratejik yaklaşımın birbirlerine alternatif olduğunu, bir işletmenin aynı anda bu stratejilerin birden fazlasını ya da hepsini uygulamasının mümkün olmadığını üstüne basarak vurgulamıştır. Şayet bir firma aynı anda hem farklılaşma hem de maliyet liderliği stratejilerini uygulamaya kalkarsa, bu durumda müşterilerine çelişkili mesajlar vererek sektör ortalamasının altında bir getiriye razı olmak zorunda kalacaktır. Porter, bu durumu ortaya çakılıp kalma (stuck in middle) olarak isimlendirmiştir. Konumlandırma okulu strateji oluştururken, tamamen diş çevreye odaklandığı ve pazarın koşullarına göre pozisyon aldığı için, bu okulun varsayımları, pazar yaklaşımı ile birebir örtüşmektedir.

\section{Farklılaşma Vakası Analizi: Setur - Select}

Setur, yeni markası Select ile A+ müşterilerine kişiye özel tatil hizmeti sunmaya başlamıştır. Kültür turlarından, gemi turlarına, yurtdışı turlarından, nehir seyahatlerine kadar birçok farklı alanda kişiye özel tatil sunan Setur, bu sayede az bilinen destinasyonları da tüketiciyle buluşturmaktadır. Sektörde çok yoğun bir rekabet olduğunu belirten Setur Genel Müdür Yardımcısı Murat Tomruk, ön plana çıkabilmek için farklılaşmanın gereklilik olduğunun altını çizmektedir. Turizmin geleceğinin "özel tatilde" olduğunu belirten Tomruk, yurtdışı tatil sunan birçok tur operatörü olduğunu, bu sektörde kişiye özel tatil tasarımları ile farklılaştıklarını dile getirmiştir (Tomruk, 2016).

\section{Maliyet Liderliği Vakası Analizi: Walmart}

Walmart, rekabetin çok yoğun olduğu perakende sektöründe satış yapan bir mağazalar zinciridir. Walmart, işletme stratejisini maliyet liderliği üzerine geliştirmiştir. Bu bağlamda (Bradley ve Ghemawat, 2002, s. 3 - 11): Genel Yönetim Giderleri üzerinde sıkı bir denetim uygulanmaktadır. Örneğin yöneticiler iş seyahatlerini uçak yerine otobüs ile yapmakta, gittikleri yerlerde mütevazı orta kalite otellerde konaklamaya teşvik edilmektedirler Mağaza kira bedelleri başta olmak üzere, sabit 
maliyetleri asgari düzeyde tutulmaya çalışılmaktadır. Her bir mağazada, o işin üstesinden gelebilecek asgari personeli istihdam edilmektedir. Mağazalar, maliyetli dekorasyondan tasarımdan kaçınılarak, gösterişsiz bir sadelikle tasarlanır.

\subsection{Girişimcilik Okulu}

Girişimcilik okulunun kurucuları Avusturyalı iktisat profesörü Peter Schumpeter ve yine Avusturyalı yönetim bilimci Peter Drucker'dır. Schumpeter girişimciliğin kişilik yapısı ile ilgili olduğunu öne sürerek, yaklaşıma psikolojik bir içerik kazandırmıştır. Diğer yandan Drucker girişimciliği, rekabet avantajı sağlayan bir kaynak olarak değerlendirmiştir (Sarvan ve diğerleri, 2003, s. 83).

Girişimcilik okulu stratejiyi mevcut durumu açıklayan sübjektif ve soyut bir süreç olarak kabul ederek, bundan önceki bölümlerde açılklanan kural koyucu stratejilerden başlangıçta ayrılır. Bu okula göre strateji liderin zihninde yaratılır. Bu bağlamda, liderin vizyon sahibi olması ve üyelerin de liderlerinin vizyonunu takip etmeleri, bu yaklaşımın belkemiğidir. Liderin vizyon sahibi olması, onun mevcut duruma farklı perspektiflerden bakabilmesine ve yapılacak yenilikler konusunda üyelerini ikna edebilmesine bağlıdır. Bu doğrultuda, lider, aynı zamanda vizyon sahibi bir girişimcidir (Thompson, 1999, s. 286). Hamilton ve Harper da (1994, s. 10), girişimciliği yaratıcı bir faaliyet olarak tanımlamışlar, bu faaliyeti başarıyla gerçekleştirebilecek kişide yüksek oranda başarma güdüsü bulunması gerektiğinin altını çizmişlerdir. Drucker'ın (1985) da değindiği gibi, lider takıntılı bir güdülenme ile vizyonunu gerçekleştirmeye odaklanır ve bu ruh hali içinde başka bir şeyi önemsemez. Bu noktada üyelerin, onun yönlendirmelerine açık olmaları gerekir. Bundan dolayı Drucker (1985, s. 27-29), girişimcilik okulunun strateji olarak, yeni kurulmuş firmalarda, krizden yeni çıkmış örgütlerde daha başarılı olacağını öne sürmüştür. Strateji geliştirme süreci tamamen liderin zihninde yer aldığ1 için, bu okul dış çevre koşullarını dikkate almaz. Stratejinin, liderin sezgi, algı ve deneyimleri ile şekillenmesi gerektiğini vurgulayıp, liderin vizyonunu taklit ve ikamesi olmayan nadir ve değerli bir kaynak olarak gördüğünden dolayı, bu okulun duruşunun kaynak tabanlı görüşe daha yakın olduğu söylenebilir (Bakoğlu ve Dinç Özcan, 2010, s. 63).

\section{Vaka Analizi: Yemeksepeti.com}

Nevzat Aydın, 1999 yılında Boğaziçi Üniversitesi Bilgisayar Mühendisliği bölümünden mezun olup, MBA yüksek lisansı için ABD'ye gitmiştir. San Francisco kentinde değişik ülke mutfaklarını tattıkça bunların sipariş yöntemlerini incelemiş ve kafasında yeni bir fikir oluşturmuştur (Vizyonun girişimcinin zihninde şekillenme süreci). Yemeksepeti fikriyle Türkiye'ye dönen Nevzat Aydın, Ocak 2001 'de siteyi açmış ve 24 yaşında kendi işinin patronu olmuştur. 2 ortağ ile siteyi kurmak için 150 bin dolar harcayan Aydın, kuruluş sermayesi için kendi birikimlerini kullanmıştır.

Fakat işin paraya dönmesi hemen gerçekleşmemiştir. İşlerin büyümesi için, Türkiye'de internetin yaygınlaşmasını sabırla beklemek zorunda kalmıştır. İş modeli çok başarılı bulunduğu için, Altın Örümcek Web Yarışması'nda 2004, 2005 ve 2006 yıllarında “Türkiye'nin En İyi Web Sitesi” ödülünü üst üste kazanmıştır. Türkiye'de e-ticaret alanında yatırım yapan şirketler arasında adını duyurmuştur (20 Mayıs 2020 tarihinde https://www.amfiweb.net/yemeksepeti-kurucusu-nevzat-aydin-kimdir/, 20 Aralık 2019 adresinden erişildi). 2015 yılında Alman menşeili Delivery Hero, 589 milyon dolar (1 milyar 596 milyon TL) toplam değerleme üzerinden Yemeksepeti hisselerinin tamamını bünyesine katmıştır. CEO Nevzat Aydın'ın Yemeksepeti'ndeki mevcut görevine devam etmekte ve Delivery Hero'nun yönetiminde aktif rol almaktadır. Yemeksepeti.com, günümüzde 62 ilde ve 10.000 'e yakın üye restoran ve aylık aldığı 3 milyon siparişle, milyonlarca kullanıcıya hizmet vermektedir. İşletme, Türkiye'nin yanı sıra başta Katar, Umman, Lübnan, Ürdün, Suudi Arabistan ve Yunanistan olmak üzere yedi farklı ülkede daha operasyonlarını sürdürmektedir. (21 Mayıs 2020 tarihinde http://www.milliyet.com.tr/yemeksepeti-589-milyon-dolara-pembenar-detay-yemek-2054297 adresinden erişildi).

\subsection{Bilişsel Okul}

Bilişsel Okul, insanların ve örgütlerin karar verirken bilgiyi nasıl işledikleri üzerine yoğunlaşmaktadır. $\mathrm{Bu}$ alandaki öncü çalışmalar Chicago Üniversitesi öğretim üyesi Herbert Simon ve Standford Üniversitesi profesörü James March’a aittir. Davidson ve Ekman’a (1994, s. 216-217) göre biliş, insan 
zihninin dış dünyayı kavramak adına gerçekleştirdiği işlemlerin tümüne verilen addır. Biliş ve bilişsel süreçleri mercek altına yatıran bilişsel psikoloji, ilgili süreçlerin anlamlı bir şekilde açıklanabilmesi için, bireyin dış uyarıcılar ile olan etkileşiminden ziyade kendi inanç, beklenti, amaç ve değerlerine odaklanır (Özden, 2000, s. 42). Strateji oluşturma süreci, örgüt üyelerinin - girişimcilik okulundaki gibi - zihninde ortaya çıkan bir süreçtir, bundan dolayı - girişimcilik okulunda söz konusu olduğu gibi - temel varsayımları, kaynak yaklaşımına daha yakındır (Bakoğlu ve Dinç Özcan, 2010, s. 63). Bu okul, stratejiyi kimin geliştireceği konusunda ise girişimcilik okulundan ayrılır, zira bilişsel okulda, lider, liderin vizyonu ve lider - üye etkileşimi gibi kavramlara dair en ufak bir vurgu söz konusu değildir. Bilişsel yaklaşım, stratejiyi geliştirenden ziyade, bu sürecin nasıl gerçekleştiğini neden sonuç ilişkileri bağlamında ayrıntılı bir şekilde açıklamaya odaklanmıştır (Lee ve Chen, 1997, s. 158).

\section{Vaka Analizi: Bilişsel Haritalama}

$\mathrm{Bu}$ okulun strateji geliştirirken kullandığı temel araçların belki de en önemlisi bilişsel haritalama yöntemidir. Bilişsel haritalar bir kişi ya da grubun davranışlarına rehberlik eden, hem ölçülebilir hem de ölçülemeyen düşünce ve olaylar arasındaki ilişkilerden meydana gelir (Chandra ve Newburry, 1997, s. 387). Bu doğrultuda, bilişsel haritalardan, gerçek hayatta ortaya çıkan problemlerin çözümlenmesi ve anlaşılması için kullanılan bir araç olarak (Kaya ve diğerleri, 2010, s. 337) veya karmaşık sistemleri modelleyip bu sistemi oluşturan bileşenlerin kendi aralarındaki neden - sonuç ilişkilerini açığa çıkarma adına, faydalanılır. (Hodgkinson ve diğerleri, 2004, s. 3). Bilişsel haritalardan, ayrıca, sanal ortamdaki bir kullanıcıyı tanımlamaya yarayan üç boyutlu grafik çizimlerinde ve nesneleri tanımakta zorlanan fabrika robotlarına, ilgili nesnelerin tanıtılmasında da faydalanılmaktadır (Özdağoğlu, 2010, s. 3).

\subsection{Kültür Okulu}

Kültür okuluna göre strateji, örgütün tüm çalışanlarının ortaklaşa katkısı ile ortaya çıkan bir süreçtir. $\mathrm{Bu}$ okulun kurucuları Stockholm Üniversitesi ekonomi profesörü Eric Rhenman, İngiliz akademisyen ve filozof Richard Norman ve Göteborg Üniversitesi İşletme Anabilim dalı profesörü Bo Hedberg'dir. Kültür okulu stratejiyi temel olarak, örgüt içinde ortaklaşa geliştirilen örgüt kültürüne dayandırmaktadır. Bu doğrultuda, strateji belirleme ideolojik bir sürece tekabül eder. Bu esnada örgüt yönetimi, kendi arzuladığı kültürü, çalışanlarına benimsetip onlar üzerinde etkin kılmak için çaba gösterir (Sarvan ve diğerleri, 2003, s. 99). Örgüt kültürü geliştirme adına aşağıda dile getirilen kavramlardan faydalanılır (Şişman, 2002, s. 84 - 101).

İnançlar, çalışanların belirli konularda, koşulsuz kabul ettikleri doğrulardır. Değerler, çalışanların çeşitli olayları değerlendirirken faydalandıkları algılardan meydana gelir. Algılar, ekseriyetle inançların üzerine inşa edilir. Normlar, çalışanlara çeşitli durumları açıklama ve yorumlamada yol gösteren yazılı olmayan, ilgili örgüte has, sosyal kural- ve standartlardır. Semboller, örgütün kültürünün, görülen veya gözlemlenebilen somut yüzünü oluşturur. Semboller fiziksel ve davranışsal semboller olarak iki gruba ayrılabilir. Çalışma yerinin dekorasyonu, çalışanların giyim- kuşamı vb. fiziksel sembollere örnek teşkil ederken, örgüt çalışanlarının kullandıkları dil, birbirlerine hitaplarındaki resmiyet seviyesi, örgütün yol gösterici addettiği kişiler vb. ile ilgili hikâyeler ise davranışsal sembollere örnek teşkil edebilirler.

$\mathrm{Bu}$ okul, stratejinin uygulanmasındaki başarı ya da başarısızlığın sorumluluğunu tamamen örgüt kültürüne yüklediği için, bazı durumlarda örgüt kültürünün kendisi, örgütsel değişimin önündeki en önemli engel olabilmektedir (Sarvan ve diğerleri, 2003, s. 100). Strateji belirleme sürecini taklit edilmesi imkânsız bir iç kaynak olan örgüt kültürüne dayandırdığından, bu okulun temel yaklaşımının, rekabet avantajını örgüt içi kanyak ve kabiliyetlerle açıklayan kaynak tabanlı görüşle paralel olduğunu söyleyebiliriz (Bakoğlu ve Dinç Özcan, 2010, s. 65).

\section{Vaka Analizi: Trader Joe’s}

Sıra dışı bir örgüt kültürünü organizasyon stratejisine dönüştürme konusunda, A.B.D. menşeili marketler zinciri Trader Joe's'den daha çarpıcı bir örnek vermek güçtür. 1967 senesinde tek bir şube ile kurulan şirket, günümüzde 22 ülkede faaliyet göstermekte ve yıllık 5 milyar dolar ciro yapmaktadır (Stanford, 2014, s. 68). 
İş stratejisini “daha çok insana semt marketi avantajı sunmak" üzerine inşa eden firma, çoğunlukla kendi markası olan ucuz ve kaliteli ürünleri müssterilerinin beğenisine sunmaktadır. Bu bağlamda, marketler özellikle "cennet ada konseptine" göre tasarlanmış olup, mağaza çalışanları birbirlerine "tayfa", market müdürüne ise "kaptan" olarak hitap etmekte, müdür dâhil tüm çalışanlar, iş esnasında "Hawaii gömleği” giymektedir. Trader Joe's’un sloganı ise "Biz denedik! Beğendik! Siz de deneyin, beğenmezseniz, paranızı sorgusuz sualsiz geri alın!” şeklindedir (Stanford, 2014, s. 68). Firma, yukarıda değinilen sıcak örgüt iklimine dayalı mağaza konseptine bağlı kalmak adına, iş geliştirme süreçlerini titizlikle yürütmektedir. $\mathrm{Bu}$ bağlamda, örgüt kültürünü benimseyip sürdürebilecek elemanların seçilmesi ve onlara örgüt kültürüyle ilgili eğitimlerin verilmesi, işletmenin başarıyla yürüttüğü insan kaynakları politikaları olarak karşımıza çıkmaktadır (Stanford, 2014, s. 68).

\section{7. Çevre Okulu}

Çevre okulu, strateji oluşturmayı, dlş̧ çevreden kaynaklanan değişikliklere verilen bir tepki olarak görür. Bu okulun kurucuları Edinburgh Üniversitesi sosyoloğu Tom Burns ve Harvard Business School profesörleri Paul Lawrence ve Jay William Lorsch'tur. 1970'lerin sonlarında geliştirilen bu yaklaşım, strateji oluşturmada en önemli rolü; bir bütün olarak, çevreye atfeder, zira işletme, bu süreçte - çevresel faktörlere bağımlı olduğundan dolayı - büyük ölçüde edilgen ve pasiftir (BakoğluDinç Özcan, 2010, s. 66). Çevre okulunu, aynı dönemde geliştirilen örgüt kuramlarının neticesinde ortaya konulmuş bir yönetim okulu olarak kabul etmek de oldukça anlamlı olabilir, çünkü çevre okulunun temel varsayımları, örgüt yazınına aynı dönemde giren kaynak bağımlığı, popülasyon ekolojisi, ve kurumsallaşma kuramlarına dayanmaktadır.

Kaynak Bağımlığı Kuramı ile İlișki: Kuramın, örgütlerin kendilerine gerekli olan kaynakları temin ettikleri dış çevreye (pazara) bağımlı olmalarına dayalı asli varsayımını kabul eder (Pfeffer-Salancik, 1978: 26). Strateji geliştirme sürecini - dış çevreyi ayrıntılı bir şekilde tanımlayarak, pazarı incelemek - de kaynak bağımlılı̆̆ı kuramından esinlenerek yürütür (Sarvan ve diğerleri, 2003, s. 101).

Popülasyon Ekolojisi Kuramı ile İlișki: Kuramın, çevrenin gerekli değişiklikleri zamanında gerçekleştiren örgütleri seçtiğini, çevresel koşulların değişimine uyum sağlayamayan örgütleri ise ayıkladığını, kabul eder (Jaffee, 2001, s. 214 - 216).

Kurumsallaşma Kuramı ile İlișki: Kuramın, aynı çevrede (pazar, sektör vb.) faaliyet gösteren işletmelerin orta veya uzun vadede - yapı ve işleyiş özellikleri açısından - birbirlerine benzeyecekleri savinı destekler (Daft, 2015, s. 165).

Çevre okuluna göre, işletmeler, hayatta kalıp başarılı olabilmek için, dış çevre koşullarına azami uyum sağlamalı ve stratejilerini de pazarda elde ettikleri bilgiye göre tasarlamalıdır. Bu noktadan hareketle, çevre okulunun strateji oluşturma prensiplerinin, pazar yaklaşımının varsayımları ile uyumlu olduğu söylenebilir (Bakoğlu ve Dinç Özcan, 2010, s. 66).

\section{Vaka Analizi: McDonald's}

Londra'nın dış banliyölerinden birine yeni bir restoran açmak isteyen McDonald's, üç güzergâh arasında seçim yapma adına çevre analizi gerçekleştirmiş, bu bağlamda aşağıda kısaca değinilen çevresel faktörlerin tümünü (müşteriler, rakipler, yazılı ve görsel medya, yerel yönetim ve hükümet) dikkate almak zorunda kalmıştır. (22 Mayis 2020 tarihinde https://www.ukessays.com/essays/marketing/marketing-environment-analysis-for-mcdonaldsmarketing-essay.php, adresinden erişildi).

Sosyal Çevre (Medya ve STK'lar): Kamuoyunda sağlıklı beslenmeyi teşvik eden eğilimin günden güne güçlenmesi, fast food restoranı açmayı güçleştirmektedir.

Politik Çevre (Hükümet): Hükümet de, hamburger vb. fast food yiyeceklerin gençlerde sağlık problemlerini tetiklediğini düşünmekte, bu sebeple fast food restoranlarının sayısını olabildiğince sınırlamak istemektedir.

Ekonomik Çevre (Müșteriler): Müşteriler, fast food restoranlarının, etnik yemek sunan restoranlara göre hem daha pahalı olduğunu, hem de sunulan hizmetin daha düşük olduğunu (masaya servisin olmayışı, müşteri ile iletişim eksikliği vb.) belirtmişlerdir. 
Lokasyon (Mekânsal Kısıt): Yeni restoran, genç nüfusun yoğun olarak kullandığı işlek bir caddede açılmalıdır. Bu tarz caddelerde kira bedelleri oldukça yüksektir.

Fast Food Pazarı (Rakipler): McDonald's, pazarda faaliyet gösteren diğer fast food zincirlerinin sundukları ürünlerin çeşitliliğini, verdikleri hizmetin kalitesini ve fiyatlandırma politikalarını sürekli takip etmek zorundadır.

Yasal Zorunluluklar (Yerel Yönetim ve İlgili Odalar): Restoran, sunduğu hizmet için gerekli olan lisans, ruhsat, kalite vb. belgeleri edinmek durumundadır. Ayrıca aynı bölgede faaliyet gösteren diğer fast food restoranlarının açılış ve kapanış saatlerine uymak zorundadır.

\section{8. Öğrenme Okulu}

Öğrenme okulu, strateji oluşturmayı zamanla kendiliğinde ortaya çıkan bir süreç olarak tanımlar. Bu okulun kurucuları şunlardır: Columbia Üniversitesi istatistik ve iktisat profesörü Richard Cyert, örgütsel öğrenme kuramının kurucusu Chris Argyris, Chicago Üniversitesi’nden davranış bilimci James March ve Iowa Üniversitesi örgütsel davranış uzmanlarından Fred Luthans ve sosyal bilimci Charles Lindblom.

Bu okul strateji geliştirme sürecinden ziyade, stratejinin iç̧eriği üzerine yoğunlaşarak, diğer okullardan temelde ayrışmaktadır. Bu doğrultuda, strateji oluşturmaya dair somut bir disiplinden bahsetmek mümkün gözükmemektedir (Sarvan ve diğerleri, 2003, s. 91 - 92; Bakoğlu-Dinç Özcan, 2010, s. 63). Cyert ve March, 1963, s. 19-22) öğrenme sürecinin örgütsel düzeyde yoğun bir iştirak ile ortaklaşa sağlanabileceğini savunmuşlardır. Bu bağlamda örgütsel öğrenme, yöneticilerin koalisyonu ve çalışanların tatmin edici onayı alınarak gerçekleştirilebilir. Dikkat edilmesi gereken diğer bir konu da örgütsel öğrenmenin, sorunların mutlak çözümünü sağlamaktan uzak olduğudur.

Luthans (1976, s. 237) ise örgütsel öğrenmenin çalışanların davranışlarında meydana gelecek değişiklikler ile gerçekleşebileceğinin altını çizmiş, bu değişikliğin ise ancak yaşanacak deneyim sayesinde orataya çıkabileceğini eklemeyi de ihmal etmemiştir. Argyris ve Schön'e (1978, s. 20-22) göre kişisel öğrenme ile örgütsel öğrenme arasında güçlü bir ilişki bulunmaktadır. Ne var ki, şahsi öğrenme örgütsel öğrenme için zorunlu olsa da, tek başına yeterli değildir. Lindblom (1979, s. 517) ise öğrenme sürecini "ufak adımlarla ilerleme" olarak tanımlamaktadır. Bu bağlamda, işletmeler ne kapsamlı stratejiler geliştirebilirler ne de bilimsel analizler yapabilirler, çünkü dış çevre öngörülmesi mümkün olmayan belirsizliklerle doludur. İşletmenin, sorunların üstesinden gelebilmek için yapabileceği yegâne şey, parça parça ortaya çıkan durumlardan bir şeyler öğrenmektir.

Sonuç olarak örgütsel öğrenme üzerine teorik çıkarımlarda bulunan bilim insanlarının üzerinde görüş birliği sağladıkları şey, stratejinin planlanarak belirlenemeyeceği, aksine, uygulamada sonrasında edinilecek tecrübeler 1şında, sonradan kendiliğinden ortaya çıkacağıdır. İşletmenin önünde belirebilecek tehdit ve firsatları önceden görüp bunlara ilişkin stratejiler tasarlamayı kasıtlı olarak ihmal etmesi okula yöneltilen temel eleştiridir (Sarvan ve diğerleri, 2003, s. 95). Zira okul, örgütsel öğrenmeyi tek temel yetkinliği olarak görerek, kaynak tabanlı görüşle birebir örtüşse de, özellikle kriz dönemlerinde örgütsel öğrenme süreçleri uzun sürebilmekte, bu da işletmenin krizden çıkabilme süresini uzatabilmektedir (Bakoğlu-Dinç Özcan, 2010, s. 64).

\section{Vaka Analizi: Deloitte}

Deloitte, 140'a yakın ülkede, 700 farklı ofiste faaliyet göstermekte olup, 180.000'i aşkın çalışanı ile dünyanın en büyük uluslararası muhasebe, denetim, vergi ve yönetim danışmanlığı hizmeti sunan firmalarından birisidir. Şirketin temel yönetim felsefesi işyerinde öğrenme süreçleri aracılığıyla çalışanlarının yetkinliklerini geliştirmek, böylelikle de örgütün toplam beşeri sermayesini artırmaktır. $\mathrm{Bu}$ bağlamda, Deloitte, çalışanlarını, örgütsel öğrenme süreçlerine katılım sağlamaya teşvik edip, onların işe adanmışlıklarını, iş motivasyonunu ve bireysel performanslarını yükseltmeyi beklemektedir. Deloitte'nin öğrenme süreci iş çıktılarına (olması gerekene değil olana) odaklıdır. Bu noktada firma, çalışanlarından, mesleki bilgi ve deneyimlerini iş hedeflerine odaklamalarını istemektedir. Teorik grup eğitimi vermektense, iş üstünde tecrübeye dayalı bireysel öğrenme süreçleri tercihedilmektedir. ( $01 \quad$ May1s $2020 \quad$ tarihinde https://www2.deloitte.com/content/dam/Deloitte/nl/Documents/humancapital/deloitte-nl-learning-and- 
development-trends-in-the-netherlands.pdf, adresinden erişildi).

\subsection{Güç Okulu}

Güç okulu strateji belirlemeyi, örgüt içinde çatışan gruplar arasında ortaya çıkan ya da örgütün dı̧̧ çevredeki rakipleriyle gerçekleştirdiği bir müzakere süreci olarak görür. Bu kuramın öncüleri Bradford Üniversitesi Yönetim Okulu örgüt kuramcılarından David John Hickson, Minnesota Üniversitesi İşletme Okulu profesörlerinden Andrew Grimes, örgütsel davranış bilimci Graham Astley ve Stanford Üniversitesi akademisyeni ve kaynak bağımlığı kuramının öncüsü Jeffrey Pfeffer'dir.

Hickson ve diğerleri (1974) bu okulun strateji oluşumunun politika ve güç ekseninde kendiliğinden ortaya çıktığını belirtmişlerdir (s. 22). Bu bağlamda, güç okulunun stratejisi bir bakış açısını yansıtmaktan ziyade, mevcut duruma ilişkin taktikler şeklindedir. Güç ile yetki arasındaki ilişkiye değinen Grimes (1978, s. 725) ise, yetkinin gücün yasal olarak meşrulaştırılmış ve kurumlaştırılmış biçimi olduğunu belirtmiştir. Günümüzde ise yetkinin gücün tek kaynağı olduğu görüşü yerini farklı güç kaynaklarının olabileceği inancına bırakmıştır. Zira yetki dışında, kişisel özellikler, deneyim, özel kabiliyetler gibi örgütün sahip olduğu çeşitli kaynaklar da birer güç kaynağı olarak kabul edilebilirler. $\mathrm{Bu}$ kaynakların hiyerarșiden bağımsız olup farklı alanlarda kullanılabilmeleri kendilerini "değerli", kaynaklara sahip olan kişi-, bölüm- ya da kurumu ise "güçlü" kılmaktadır (Astley ve Sachdeva, 1984, s. 105-108). Aslen iki farklı güç alanı söz konusudur: Mikro güç alanı ve makro güç alanı (Dikili, 2014, s. 157).

Mikro güç alanının kapsamı örgüttür. Örgütün alt birimleri arasında bir işbirliği ya da uzlaşı söz konusu değildir, aksine, her bir alt birim diğeri ile yoğun rekabet içinde olduğundan ötürü; söz konusu olan örgüt içi çatışmadır. Bu durumda, örgüt için gerekli olan kaynakların elde edilmesinde en çok payı olan bölümler, diğer birimlere nazaran kesinlikle daha çok güç elde ederler (Provan ve diğerleri, 1980, s. 202). Dikili’ye (2014, s. 157-158) göre, bazı durumlarda, güç örgüt içinde kurumsallaşmış da olabilir. Belirli sorunların çözümünden (kaynak temini, ürünlerin satılması) sadece belirli alt birimler (satın alma, satış) sorumlu olabilir. Örgüt için kritik olan kaynakları elinde bulunduran alt birimler de diğer bölümlere nazaran büyük bir güce sahip olabilirler. Örneğin, devlete iş yapan inşaat firmalarında genellikle imar bakanlığı ile yapılan sözleşmelerden ve iş süreçlerden şirketin hukuk bölümü sorumludur.

$\mathrm{Bu}$ bölümün performansı, şirket için kritik bir öneme sahip olduğundan dolayı, hukuk biriminin muhasebe, finans, satın alma, insan kaynakları, satış vb. birimlere göre örgüt içi gücü çok daha fazladır. Makro güç alanının kapsamı ise örgütün faaliyet gösterdiği çevredir. Mintzberg ve diğerlerine (1998, s. 234-237) göre, makro seviyedeki güç ilişkisinde örgüt, çevresi ile karşılıklı bağımlılığa tabi sosyal bir aktördür. Burada atlanmaması gereken, güç okulunun stratejisinin örgüte azami faydayı sağlayamayacağıdır. Zira işletme her halükarda kaynak temini için faaliyet gösterdiği çevreye bağımlıdır ve piyasada kendi istem- ve gücü haricinde ortaya çıkan durumlar, stratejisini kusursuz yürütmesini engellemektedir (sınırl rasyonellik) (Simon, 1955, s. 100-101). Diğer yandan, gücü örgütün sahip olduğu bir kaynak olarak değerlendirdiği için, bu okulun çıkarımlarının, kaynak tabanlı görüşün çıkarımlarıyla uyumlu olduğu söylenebilir (Bakoğlu ve Dinç Özcan, 2010, s. 66).

\section{Vaka Analizi: Toyota ve Honda Vakaları}

Farklı ülkelerden şirketlerin kurmuş oldukları ortak girişimlerde yerli ortak genellikle yerel pazar bilgisine sahipken, yabancı ortağın güçlü yönü ise yerli ortağın henüz vakıf olamadığı yüksek teknolojiye dayalı üretimdir. Sabancı - Toyota 1990'da, Anadolu - Honda ise 1992 yılında ortaklık başlatmışlar, her iki ortak girişim de 2001 yılında son bulmuş, Her iki ortaklığın ömrü de; yabancı ortağın zaman içinde kritik kaynakları ele geçirmek suretiyle ortaklıkta daha güçlü konuma gelmesi sebebiyle, kısa süreli olmuştur. Ortaklığın başlangıcında yabancı ortak (Toyota ve Honda) yerel ortağın (Sabancı ve Anadolu) pazar bilgisine, dağıtım kanallarına ve yasal bağlantılarına sahip değildir. Üretim teknolojisi ve know-how'ı elinde bulundurmasına rağmen yabanc1 ortak, işlerin nası1 yürüdüğüne dair yerel süreçlerden bihaber olduğundan ötürü, yerel ortağa mutlak bağımlıdır ve güçlü olan, kritik kaynakları da elinde bulunduran yerli ortaktır (Güner-Gürler, 2011, s. 703 - 704).

Bir süre sonra yabancı ortak yerel ortağın pazar bilgisine ve yasal bağlantılarına ortak olur ve yerel 
ortağın, ortaklığa olan katma değeri gitgide azalır. Bu durum, kritik kaynakları ve güç dengelerini değiştirir. Yeni kritik kaynaklar artık yerli ortağın bir türlü sahip olamadığı yabancı ortağın üretim teknolojisi ve know - how'ıdır. Bundan dolayı, müzakere gücü, artık, yabancı ortağa geçmiştir.

Ortak girişimleri inceleyen Inkpen \& Beamish (1997), finansal yapıları çok güçlü olan yabancı ortakların uzun vadede yerli ortağın pazar bilgisini de edindikten sonra ortak girişimi en kısa sürede sonlandırmak isteyeceklerini belirtmişlerdir (s. 187). Bu örnekte de süreç benzer şekilde gelişmiş, Türkiye otomotiv pazarını kavrayan ve yasal bağlantılara ulaşan Toyota ve Honda firmaları da bir süre sonra yerli ortaklarıyla ortak girişimleri sonlandırarak, pazara doğrudan girmeyi tercih etmişlerdir (Güner-Gürler, 2011 s. 704).

\subsection{Yapısal Dönüşüm Okulu}

Alfred Chandler'in strateji ve yapı üzerine çı̆̆ır açan eseri Henry Mintzberg'e ilham kaynağı olmuştur. Mintzberg tarafindan geliştirilen bu yaklaşım İngilizcede "Configuration School" olarak adlandırılmakta olup, ülkemiz yazınına "Biçimleşme Okulu" olarak tercüme edilmiştir. Lakin bu çalışmanın yazarı, biçimleşme kelimesinin bu okulun temel niteliklerini ortaya koymada yetersiz kaldığı kanısındadır. Bundan dolayı, ilerleyen bölümler boyunca yaklaşım, "yapısal dönüşüm okulu" olarak adlandırılacaktır. Alfred Chandler’e göre, sanayi işletmelerinin yaşam döngüsü, kaynakların temin edildiği evre, temin edilen kaynakların verimli bir şekilde kullanıldığı evre, işletmenin pazarın sınırlarına ulaşana kadar büyüdüğü evre ve yeni pazarlara açılmanın zorunlu olduğu evre olmak üzere dört evreden oluşmaktadır (Sarvan ve diğerleri, 2003, s. 106).

Bu bağlamda, örgütler, ilk evreden son evreye kadar, belirli bir stratejiyi benimserler, örgüt yapısını da bu stratejiye uyumlu olacak şekilde tasarlarlar. Son evreye eriştiklerinde ise istikrar dönemi son bulur. Zira örgüt risk alarak bilinmeyen pazarlara açılmak zorundadır. Yeni piyasa ve dış çevre koşulları, yeni rakipler, yeni müşteriler, yeni tedarikçiler vb. demektir. $\mathrm{Bu}$ durumdan örgüt yapısının etkilenmemesi mümkün değildir. Örgüt yeni alt birimler oluşturmak ya da yapısını yenilemek suretiyle bu değişime cevap verir. Bu koşullar altında, geliştirilecek stratejinin yeni örgüt yapısını takip etmesi gerekmektedir. Dolayısıyla, stratejik yönetimin temeli, çoğu zaman istikrarı korumak, ancak zaman zaman zorunlu hale gelen dönüşüm ihtiyacını çabuk fark ederek - işletmeyi krize sokmadan - değişim sürecini yönetmeyi başarabilmektir. Bu doğrultuda geliştirilen strateji, daha önce bahsi geçen okulların yaklaşımlarından yeri geldiği zaman faydalanır (Miller ve Friesen, 1980 s. 605 - 606). Sonuç olarak, bu okulun varsayımları, diğer okulların tüm varsayımlarını kapsayıcı niteliktedir. Diğer yandan, yapısal dönüşüm okulu diğer tüm okullardan farklı olarak, uzamsaldır bir niteliktedir: Stratejinin ömrü bir dönüşüm süreciyle sınırlandırmıştır (Mintzberg, 1983, s. 344 - 347).

Ayrıca, yapısal dönüşüm okulu, strateji oluşturma sürecinde, zaman zaman pazar yaklaşımının, zaman zaman da kaynak tabanlı görüşün çıkarımlarının geçerli olabileceğini vurgulayarak aslında her iki yaklaşımı bütünleştirmektedir (Bakoğlu ve Dinç Özcan, 2010, s. 66).

\section{Vaka Analizi: Türkiye’de Özel Televizyon Örgüt Yapılarının Dönüşümü}

Kuruluş yıllarında özel televizyonların program yapısı incelendiğinde, haber bültenleri dışında yerli yayınlarının olmadığ 1 görülmektedir. Bu dönemde, en popüler yerli programlar, ekonomik olması ve üretim altyapısının kolaylığı nedeni ile talk şovlar olmuştur (Çelenk, 2003, s. 203). Bu yıllarda özel televizyonlar, yukarıdan aşağıya doğru dikey yüksek hiyerarşiye sahip geleneksel fonksiyon temelli örgüt yapısına sahiplerdi (Koçer-Erdoğmuş, 2011, s. 237). İlerleyen yıllarda, televizyonlarda iç yapımların sayısı artış gösterince stüdyolarda bir kaç program aynı anda yapılmaya başlanmıştır. $\mathrm{Bu}$ gelişme, proje ve ürün alanlarını içeren yatay yapılanmalara şiddetle ihtiyaç duyulduğunu ortaya koymuş, örgüt yapıları da hem dikey hem de yatay hiyerarşiyi içeren matris örgüt yapılarına dönüşmeye başlamıştır. Matris örgüt yapısına uygun olacak şekilde, programa odaklanmış proje ekibi ile uzmanlık yönelimli personel, yeni ve yapıcı bir şekilde harmanlanmıştır. Bu yapının bir diğer özelliği de otorite, sorumluluk ve hesap vermede çalışanın hem program yöneticisine hem de idari şefine bağlı olduğu ikili bir yapının söz konusu olmasıdır (Ford- Randolph, 1992, s. 269). Son yıllarda ise, yapımların riskini yapım şirketleri ile paylaşmak, kendi bünyesinde $\mathrm{Ar}$ - Ge birimi oluşturmaksızın yeniliklerden faydalanmak, işlem maliyetini düşürmek vb. sebeplerle, özel televizyonlar, yapım şirketlerine yönelmektedir. Bu durumda, özel televizyon kuruluşlarının, temel 
yetenekleri haricindeki işleri dış kaynak kullanıp başka işletmelere devrederek, şebeke tipi örgüt yapılarına geçtikleri gözlemlenmektedir (Koçer-Erdoğmuş, 2011, s. 240).

\section{SONUÇ}

Bu çalışmada kavramsal çerçevesi Henry Mintzberg tarafından çizilen on farklı stratejik yönetim okulu, işletme düzeyi temel stratejileri olan pazar yaklaşımı ve kaynak tabanlı görüş açısından incelenmiştir. 1960'll yillarda tasarım okulu, 1970'lerde planlama okulu, 1980'lerde ise pozisyon okulu egemenlik dönemleri geçirmişlerdir.

Şekil 2. Stratejinin Niteliğine Göre Yönetim Okullarının Karşılaştırılması

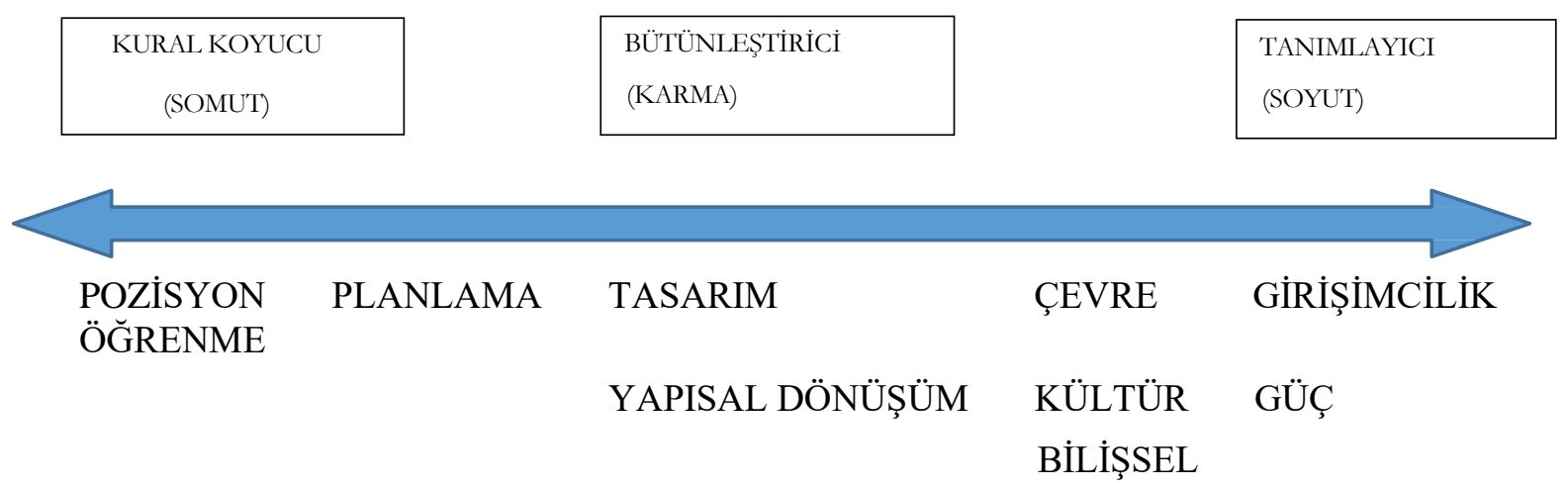

Şekil 2'den anlaşılacağ üzere, pozisyon okulu sadece stratejinin nasıl olması gerektiği ile yetinmemiş, ayrıca hangi şartlarda hangi stratejilerin (maliyet liderliği, farklılaşma, odaklanma) izleneceğini de ayrıntılı bir şekilde açıklanmıştır. Bu sebepten ötürü, pozisyon okulunun stratejisi, yine kendisi gibi kural koyucu bir okul olan planlama okulununkinden daha somuttur. Tasarım ve yapısal dönüşüm okulları ise strateji belirlerken hem kural koyucu hem de tanımlayıcı öğelerden yeri geldiğince faydalanarak, bütünleştirici bir yaklaşım sergilemektedirler.

Özellikle kaynak tabanlı görüşün etkisini attırdığı 1990'lı yıllardan itibaren ise, yönetim okulları stratejiyi, mevcut durumu soyut bir şekilde tanımlayarak açıklamayı tercih etmeye başlamışlardır. Yine de bu okullar arasında bir sıralama yapmak mümkün olabilir. Dış çevre koşullarını göz önüne alan çevre okulu, bilişsel haritalama metotlarından faydalanan bilişsel okul ve örgüt çalışanlarının inanç, değer, norm ve sembollerini temel alan kültür okulu her ne kadar strateji belirlerken somut planlar yapmasalar bile, mevcut durumu nispeten somut (gözle gözlemlenebilir) temellere dayandirmaktadırlar.

Buna karşıllk, stratejiyi örgüt içindeki politikalara dayalı müzakere sürecini olarak kabul eden güç okulu ile liderin zihninde oluşan bir sürece bağlayan girişimcilik okulunun strateji tanımlarının, çevre, biliş ve kültür okulunun tanımlarından daha soyut olduğu söylenebilir. Yine de her iki okulun strateji yaklaşımı, öğrenme okulunun yaklaşımı kadar izafi değildir. Her ne kadar soyut olsa da, müzakere süreci sonunda tüm taraflar, örgüt içindeki gücü kimin elinde tuttuğu konusunda göreceli olarak hemfikirdir. Az ya da çok herkes kritik (stratejik) kaynaklara sahip olanın, örgüt içindeki karar süreçlerine daha çok etki edeceğinin farkındadır. Diğer yandan girişimcilik okulunun liderinin zihninde şekillenen strateji, başlangıçta soyut olsa da, örgütün tüm çalışanlarına lider tarafindan aktarılır ve böylelikle, tüm iş görenler - her birinin algısı farklı da olsa - nispeten ortak bir vizyon etrafinda kenetlenir.

Lakin öğrenme okulu, mevcut durumun zamanla bir öğrenme sürecine dönüşeceğini savlarken, bu sürecin nasıl olabileceğine, hangi temellerden yararlanabileceğine ve bu sürece kimlerin aracıllk edeceğine dair herhangi bir açıklama yapmamıştır. Okulun temel savı olan, öğrenmenin her bir iş gören için farklı biçimlerde belireceğini açıklaması ise, bu okulun yaklaşımını iyice soyutlaştırmaktadır: Her bir çalışan farklı algılara ve farklı davranış kodlarına sahip olduğundan dolayı, soyut da olsa, üzerinde görüş birliğine varılmış bir stratejiden bahsetmek kolay olmayabilir.

Diğer yandan pazar yaklaşımı ve kaynak tabanlı görüş açısından okulları değerlendirdiğimizde ise, 
pozisyon, çevre ve planlama okullarının pazar yaklaşımına, bilişsel okul ile kültür, güç, girişimcilik ve ögrenme okullarının ise kaynak tabanlı görüşe yakın durduklarını söyleyebiliriz. Tasarım ve yapısal dönüşüm okulları her iki görüşü bütünleştirici bir yaklaşıma sahiptirler.

Günümüz karmaşık piyasa koşullarında, hangi yönetim okulunun strateji yaklaşımının tercih edilebileceği, önemli bir soru olarak karşımıza çıkmaktadır. Bu bağlamda ortaya çıkan okullar arasında, güç okulu, ittifaklara ve ortaklaşa stratejilere (stratejik iş birlikleri, ortak girişimler) yaptığı vurgu ile öne çıkmaktadır. Ayrıca bilişsel psikolojiye artan ilgi ve bilişsel haritalama gibi karmaşık yöntemler, bu okulun da güncelliğini korumasını sağlamaktadır. Ama örgüt bilimcilerin esas olarak odaklandıkları iki yaklaşım, örgütsel öğrenme süreçleri aracılığıyla öğrenme okulu ve de örgütsel değişim süreçleri bağlamında yapısal dönüşüm okuludur (Sarvan ve diğerleri, 2003, s. 116). Diğer yandan, örgüt stratejisi belirleme süreçlerinin kavranmasında tek bir yönetim okulunun bakış açısından yola çıkmak konuyu oldukça basitleștirmek olacaktır. Zira Mintzberg kendisini eleştirenlere, bütün kuramların aslında yapay olduğunu belirtmiştir. Aslında tüm kuramlar kâğıt üzerindeki sözlerden ibarettir. Gerçek ise her zaman kuramdan daha karmaşık olduğundan dolayl, yöneticiler kusurlu kuramlar arasında seçim yapmak zorundadırlar (Mintzberg, 1998, s. 344 - 345).

\section{Bilgilendirme / Acknowledgement:}

Yazar aşağıdaki bilgillendirmeleri yapmaktadır:

1- Makalemizde etik kurulu izni ve/veya yasal/özel izin alınmasını gerektiren bir durum yoktur. Makalede nitel/nicel, kesitsel veya boylamsal bir araştırma yapımladığı için ve kullanılan vaka analizleri geçmişte yapılmış analizlerin derlemesi şekilde sunulduğundan, etik kurulun onayına gerek duyulmamıştır.

2- Bu makalede araştırma ve yayın etiğine uyulmuştur.

\section{KAYNAKÇA}

Argyris, C., Schön, D. A. (1978). Organizational learning: A theory of action perspective. Massachusetts: MA: Addison-Wesley Publishing Company.

Astley, W. G. ve Sachdeva, P. S. (1984). Structural sources of intraorganizational power: A theoretical synthesis. Academy of Management Review, 9(1), 104-113.

Bakıroğlu, R. ve Dinç Özcan, E. (2010). İşletme düzeyi strateji paradokslarının Mintzberg'in on stratejik yönetim okulu açısından değerlendirilmesi. Öneri Dergisi, 9(34), 57-69.

Bal, Y. (2010). Rekabet avantajı yaratmada kaynak temelli yaklaşım bağlamında insan kaynaklarının rolü. Selçuk Üniversitesi İIBF Sosyal ve Ekonomik Araştırmalar Dergisi, 10(20), 267-278.

Bamberger, I. ve Wrona, T. (1996). Ressourcenansatz und seine bedeutung für strategische unternehmensführung. Zeitschrift für Betriebswirtschaftliche Forschung, Heft 2, 130-153.

Barca, M. (2009). Stratejik yönetim düşüncesinin gelişimi. Dosya, Ankara: Ankara Sanayi Odası.

Barney, J. (1991). Firm resources and sustained competitive advantage. Journal of Management, 17(1), 99-120.

Barney, J. ve Wright, M. ve Ketchen, D. Jr. (2001). The resource-based view of the firm: Ten years after 1991. Journal of Management, 27(8), 625-641.

Bea, F. ve Haas, J. (2005). Strategisches management. Stuttgart: Lucius \& Lucius Verlag.

Bradley, S. P. ve Ghemawat, P. (2002) Wal-Mart stores, Inc. Case study. Cambridge, Massachusetts: Harvard Business School Publishing.

Chandra, R. ve Newburry, W. (1997). A cognitive map of the international business. International Business Review, 6(4), 387-410. 
Coca-Cola. Ansoff matrix. 27.5. 2020 tarihinde https://themarketingagenda.com/2015/03/28/COCACOLA-ANSOFF-MATRIX/, adresinden erişildi.

Cyert, R. M. ve March, J. G. A behavioral theory of the firm (1963). Malden: Massachusetts: Blackwell Publishers Ltd.

Çelenk, S. (2003). Televizyonda içerik yapılaşması ve toplumsal kültür yayın akışı ekseninde eleştirel bir inceleme. Yayımlanmamış doktora tezi. Ankara Üniversitesi Sosyal Bilimler Enstitüsü, Ankara.

Daft, R. L. (2015). Örgüt: kuramları ve tasarımını anlamak. Çeviren Prof. Dr. Ömür Timurcanday Özmen. Ankara: Nobel Akademik Yayıncılık.

Davidson, J. R. ve Ekman, P., Scherer, K. (1994). The nature of emotion: Fundamental questions. New York: NY: Oxford University Press.

Deloitte (tarihsiz). Learning and development trends in the Netherlands. Investigating multinationals. $1 \quad$ Mayis $2020 \quad$ tarihinde https://www2.deloitte.com/content/dam/Deloitte/nl/Documents/humancapital/deloitte-nllearning-and-development-trends-in-the-netherlands.pdf adresinden erişildi.

Dinçer, Ö. (2013). Stratejik yönetim ve işletme politikası. İstanbul: Alfa Yayınları.

Dikili, A. (2014). Eleştirel yönetim çalışmaları ile kaynak bağımlılı̆̆ı yaklaşımının bakışlarına dair karşılaştırmalı bir analiz. Yönetim Bilimleri Dergisi, 12(23), 141-164.

Drucker, P. (1985). Innovation and entrepreneurship: Practice and principles. New York: NY: Harper \& Row Publishers.

Ford, R. C. ve Randolph, W. A. (1992). Cross functional structures: A review and integration of matrix organization and project management. Journal of Management, 18(2), 267-294.

Girişimcilik: Yemek sepeti kurucusu Nevzat Aydın kimdir?, 20 May1s 2020 tarihinde https://www.amfiweb.net/yemeksepeti-kurucusu-nevzat-aydin-kimdir/, adresinden erişildi.

Grimes, A. J. (1978). Authority, power, influence and social control: A theoretical synthesis. Academy of Management Review, 3(4), 724-735.

Güner, S. ve Gürler, G. (2011). Kaynak bağımlı̆̆ı teorisi çerçevesinde stratejik işbirliklerinin değerlendirilmesi: Örnek olay çalışması olarak Toyota - Honda vakaları. 3. Uluslararası Balkanlarda Sosyal Bilimler Kongresi, 30-31 Mayıs 2011, Mostar, Bosna - Hersek.

Hamilton, M. T. ve Harper, J. H. (1994). The entrepreneur in theory and practice. Journal of Economic Studies, 21(6), 3-18.

Henry, A. (2008). Understanding strategic management. Oxford: UK: Oxford University Press.

Hickson, D. J. ve Hinings, C. R. ve Pennings, J. M. ve Schneck, R. E. (1974). Structural conditions of intraorganizational power. Administrative Science Quarterly, 19(1), 22-44.

Hodkinson, G. P. ve Maule, A. J. ve Bown, N. J. (2004). Causal cognitive mapping in the organizational strategy field. Organization Research Methods, 7(1), 3-26.

Inkpen, A. C. ve Beamish, P. W. (1997). Knowledge bargaining power and the insatbility of international joint ventures. Academy of Management Review, 22(1), 177-202.

Jaffee, D. (2001). Organization theory: Tension and change. Singapore: Mc Graw-Hill Publishing, 2001.

Kaya, M. D. ve Haşıloğlu, A. S. ve Haşıloğlu, S. B. (2010). Girişimci web sayfalarının değerlendirilmesinde bulanık bilişsel haritalama yönteminin kullanımı. EKEV Akademi Dergisi, 14(44), 335-342.

Knecht, M. (2014). Diversification, industry dynamism and economic performance: The impact of dynamicrelated diversification an the multi-business Firm. Wiesbaden: Springer Gabler 
Verlag.

Koçer, S. ve Erdoğmuş, N. (2011). Türkiye'de özel Televizyon kuruluşlarının örgüt yapılarının dönüşümü. Eskişehir Osmangazi Üniversitesi IIIBF Dergisi, 6(2), 235-262.

Lee, S. M. ve Chen, J. Q. (1997). A conceptual model for executive support systems. Logistics Information Management, 10(4), 154-159.

Lindblom, C. E. (1980). Still mudding, not yet through. Public Administration Review, 40(6), 517-526.

Luthans, F. (1976). Introduction to management: A contingency approach. New York: NY: Mc GrawHill Publishing.

Miller, D. ve Friesen, P. H. (1980). Momentum and revolution in organizational adaptation. Academy of Management Journal, 23(4), 591-614.

Mintzberg, H. (1994). The fall and rise of strategic planning. Harvard Business Review, January February Special Issue, 107-114.

Mintzberg, H. (1983). Power in and around organizations. Englewood Cliffs NJ: Prentice Hall Publishing.

Mintzberg, H. ve Ahlstrand, B. ve Lampel, J. (1998). Strategy safari. New York: NY: Free Press Publishing.

Morgan, R. M. ve Hunt, S. (1999). Relationship-based competitive advantage: The role of relationship marketing in marketing strategy. Journal of Business Research, 46(3), 281-290.

Özdağoğlu, A. (2010). Bilişssel haritalama ve analitik serim süreci (ASS) entegrasyonu. Yönetim ve Ekonomi, 17(1), 1-10.

Özden, Y. (2000). Öğrenme ve öğretme. Ankara: Pegem Yayınc1lık, 2000.

Pearce, J.A. ve Robinson, R. B. (2015). Stratejik yönetim. Çeviren Mehmet Barca. İstanbul: Nobel Yayıncilik.

Pfeffer, J. ve Salancik, G. (1978). The external control of organizations: A resource dependence perspective. New York: NY: Harper \& Row Publishing.

Porter, M. E. (1985). Competitive advantage: Creating and sustaining superior performance. New York: NY: Free Press.

Porter, M. E. (1980). Competitive strategy. New York: NY: Free Press.

Provan, K. G. ve Beyer, J. M. ve Kruytbosch, C. (1980). Environmental linkages and power in resource-dependence relations between organizations. Administrative Science Quarterly, 25(2), 200-225.

Rothaermel, F. (2013). Strategic management: Concepts. New York: NY: McGraw Hill Publishing.

Sarbah, A. ve Otu-Nyarko, D. (2014). An overview of design school of strategic management. Open Journal of Business and Management, 2(3), 231-249.

Sarvan, F. ve Durmuş Arıcı, E. ve Özen, J. ve Özdemir, B. ve Tarcan İçigen, E. (2003). On stratejik yönetim okulu: Biçimleşme okulunun bütünleştirici etkisi. Akdeniz I.I. B.F. Dergisi, 3(6), 73122.

Simon, H. (1955). Behavioral model of rational choice. Quarterly Journal of Economics, 69(1), 99118.

Stanford, N. (2014). Organizasyon kültürü. Düzenleyen Ali Berktay. Çeviren Ümit Şensoy. İstanbul: İş Bankası Yayınları.

Şişman, M. (2002). Örgütler ve kültürler. Ankara: Pegem Yayıncılık.

Teece, D. (1984). Economic analysis and strategic management. California Management Review, 
26(3), 87-110.

Thompson, J. L. (1999). A strategic perspective of entrepreneurship. International Journal of Entrepreneurial Behaviour \& Research, 5(6), 279-296.

Tomruk, M. (2016). En özel tatil. röportajı yapan: B. Coşan. (30.04.2016).

UK Essays. Marketing environmental analysis for McDonald's marketing essay. 27 May1s 2020 tarihinde https://www.ukessays.com/essays/marketing/marketing-environment-analysis-formcdonalds-marketing-essay.php adresinden erişildi.

Wernerfelt, B. (1984). A resource based view of the firm. Strategic Management Journal, 5(2), 171180.

Wolf, J. (2005). Organization, management, unternehmensführung: theorien und kritik. Wiesbaden: Gabler Verlag.

Yemek Haberleri. Yemek sepeti 589 milyon dolara satıldı. 21 Mayıs 2020 tarihinde http://www.milliyet.com.tr/yemeksepeti-589-milyon-dolara-pembenar-detay-yemek-2054297, adresinden erişildi. 